\title{
Investigation on the Industrial Drying Processes
}

\author{
T.Venkateshan ${ }^{1}$, M. Easwaramoorthi ${ }^{2}$ \\ ${ }^{I}$ PG Scholar, Department of Mechanical Engineering, Nandha Engineering College, Erode, Tamilnadu, India \\ ${ }^{2}$ Professor, Department of Mechanical Engineering, Nandha Engineering College, Erode, Tamilnadu, India
}

\begin{abstract}
The non-renewable energy sources, their current consumption rates and their future availability have emerged as the areas of concentration which is mainly because of the growing needs and utilizations by the population. The current target of the government and researchers is to bring about an energy source that should be an alternative option for the depleting fuels. Further, the harmful effects of these fuels have to be considerably reduced so that they are eco-friendly in nature. The intended solution for these global energy crises could be the Hybrid Solar energy systems. In order to address these facts, an industrial survey has been conducted in the peripheral areas of Perundurai, Erode District of Tamil Nadu. A batch of nearly 30 industries has been investigated for the industrial survey to understand the real condition requirements of the drying processes and to analyse the scope for implementing the alternative solutions for drying processes in these industries by means of Hybrid solar energy systems.
\end{abstract}

Keywords: solar dryers, solar air heaters, hybrid solar energy systems, drying processes, paddy processing

\section{Introduction}

Drying process helps in removing moisture in the products. In case of effective storage purpose, the products have to be prevented from the activities of microorganism, and in case of easy transportation purpose, the bulk weight have to be reduced. Sometimes the heat energy from the Sun may be useful for drying the wet paddy in the rice mills. In olden days, thermal food drying had been practised for many years. The thermal food drying using the energy of the Sun is a very simple method. Open sun drying is a direct mode drying in which the products are directly exposed to the sun's radiation. Otherwise, in case of the indirect mode drying, the products are kept in a drying chamber and heated directly or indirectly. The open sun drying does not require great skill; the practice has become the most preferred method in villages. But the open sun drying holds many disadvantages one of which is the poor quality of the dried products.

The harnessed thermal energy from the Solar dryer could be utilized effectively and as a result the quality of the final products could be improved. The Solar dryers have quickened the drying processes by reducing the relative humidity and increasing the mobility rate of dry air. Further, the faster drying rate prevents the risk of spoilage of products. In order to study the feasibility of implementing the Solar dryers for domestic purpose drying processes, the following work had been initiated.

In India, almost 85 million tonnes of paddy have been processed per year for the huge population (Shweta et al. 2011). Further, in the context of global energy crisis, the possibilities of reducing the consumption of energy have been explored by all the countries. The Socioeconomic development of any country strongly depends on their energy sources and their utilization. Particularly in the case of farm products like paddy, it has become very important to conserve energy by its efficient utilization (Goyal et al. 2014).

\subsection{Objectives:}

In view of the above facts, a study on the commercial rice mills had been conducted to perform the cost-benefit analysis of different processing methods and propose the most effective one. The objectives of this work are

a) To study the various types of rice processing technologies.

b) To study the electrical energy utilization for the paddy drying process.

c) To propose improvement for the processing by means of Solar dryers.

\section{Materials and Methods}

Erode is one of the major paddy growing areas in Tamil Nadu and has more number of rice mills. In this district, Perundurai taluk consists of numerous rice mills which are almost getting modernised leaving only a few.

The Conventional rice mills consist of units having steel hullers for paddy processing. This has been an age old and inefficient technology. Different activities in these mills like paddy cleaning, drying, grading, rice polishing, etc., are carried out manually. 
The Modern rice mills consist of the units possessing rubber roll shellers for paddy processing. This has been a modern and efficient technology. The majority of the rice mills activities have been performed with machineries like aspirators, driers, polishers, graders, etc.

\subsection{Site Selection:}

In this study, a batch of nearly 30 commercial rice mills in the peripheries of Perundurai Taluk had been considered and visited for the survey purposes. These mills include both traditional and modern type rice mills.

\subsection{Collection of Data:}

Field surveys have been conducted during the period from November 2015 to February 2016 in the selected rice mills for collecting necessary information about their energy utilization and study the processing conditions. A simple questionnaire had been prepared for this data collection purpose. The data have been collected by direct interview with the mill managers, owners, supervisors, technical persons and workers working in the mills. The relevant information provided by them were recorded and verified to be sure that the details were reasonably correct.

In case of these surveyed mills, the parboiled rice has been processed as this becomes common practice in Tamil Nadu. The parboiled rice refers to the rice that has been processed after water heating treatment (boiling/ steaming) to the paddy. In this study a comparison between the modern rice mills and traditional rice mills could be done.

\section{Industrial Survey}

In addition to the literature evidence, the real industrial conditions have been analyzed to focus in implementing the Solar hybrid drying systems. For this purpose, the Industrial survey regarding the energy utilization and type of processing had been carried out. The summary of the industrial survey has been provided in Table 1 and 2.In case of traditional rice mills, the electrical energy requirements for the drying process are very low as they adopt open sun drying. But in considering the modern rice mills, the blowers and dryers consume very huge electrical energy. A detailed study on the electrical and thermal energy use in selected rice mills was performed. Data on the horsepower of motors in the dryer units were also recorded. The analysis has been done considering the traditional and modern mills as separate categories. The following table lists the traditional rice mills considered for study.

[Refer Appendix - 1 for Table 1].

Table 1 explains the details considered in the traditional rice mills in which no electrical energy has been required for drying. The electrical usage mentioned in Table 1 refers to consumption for milling purposes. The Continuous Flow Dryer has been used in modern rice mills for large commercial facilities. The capacity of this dryer is approximately about 10tonne/hour. The system has positives like high capacity and automatic operations. The details corresponding to the modern rice mills are given in Table 2.

[Refer Appendix - 2 for Table - 2].

In case of Modern rice mills, the Plate fin heat exchangers are used for the drying purposes. This type of heat exchanger has been used in the dryer setup which is very essential for drying boiled paddy products before milling process.

The details provided in Table 2explain the amount of energy consumed in the modern rice mill operations. The modern rice mills have been in need of more electrical energy for the drying purposes. The electrical usage mentioned in Table 2 refers to consumption for drying and milling purposes. The dryer setup used in modern rice mills is shown in Figure 1.

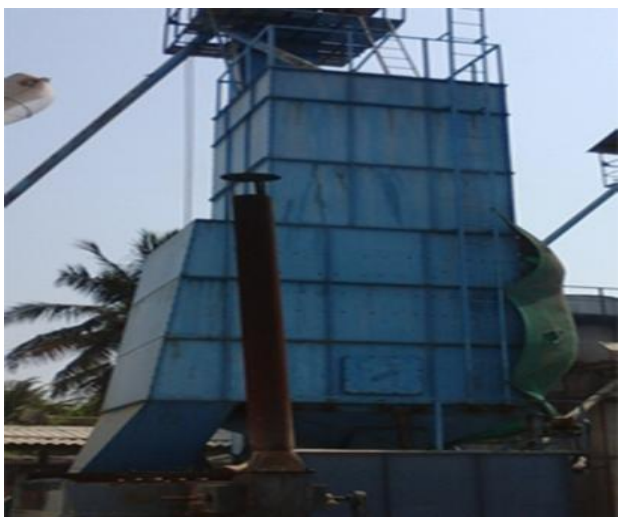

Figure 1: The Dryer Setup 
The dryer setup shown in Figure 1 refers to the Plate fin Heat Exchanger for drying the paddy after crossing the stage of the blower. Further, the heat energy supplied to the dryers refers to the heat energy from the steam supplied from a boiler. This heat energy has been extracted by using Heat Exchanger.

\section{Energy Utilization}

The energy utilized in the rice mills has been estimated considering the electrical and thermal energy neglecting the manual energy. The electrical energy consumed had been referred in terms of kilowatt hours. The thermal energy required for processing had been referred in terms of kilowatt hours or kilojoules. The energy consumed in Traditional rice mills had been shown in Figure 2.

\subsection{Energy consumption in Traditional Rice Mills:}

\section{Traditional Rice mills (Energy} consumption)

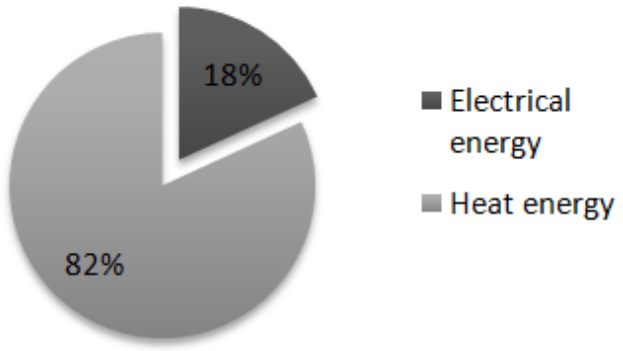

Figure 2: Energy Consumption Chart in Traditional Mills

Figure 2explains the electrical and energy consumption in the traditional rice mills. There is no requirement of electrical energy for paddy drying in these mills. The electrical usage mentioned in Table 1 refers to consumption for milling purpose. Further, the heat energy supplied refers the energy from fuel combustion provided for steaming (boiling) the paddy. Since, the open sun drying has been followed here; the heat energy for drying the products is not required. The average electrical energy consumption for milling the rice is about $100 \mathrm{kWh} /$ tonne to $225 \mathrm{kWh} /$ tonne. The average heat energy supplied for boiling the paddy had been found to be in the range of 600 to $750 \mathrm{kWh} /$ tonne. The energy consumed in Modern Rice Mills had been shown in Figure 3.

\subsection{Energy consumption in Modern Rice Mills:}

Modern Rice Mills (Energy Consumption)

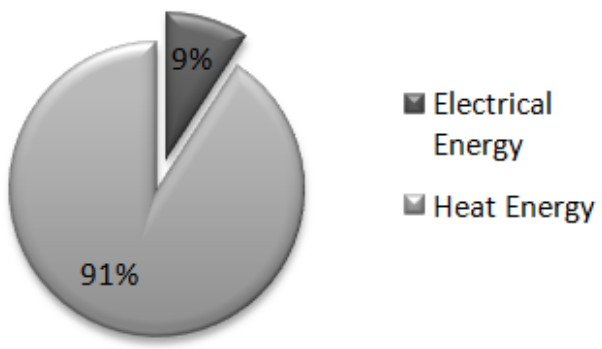

Figure 3: Energy consumption chart in Modern Rice Mills

The chart given in Figure 3 explains the amount of energy consumed in the modern rice mill operations. The modern rice mills have been in need of more electrical energy for the drying purposes. The electrical usage mentioned in the case of these mills refers to consumption for drying and milling purposes. Further, the heat energy supplied refers the energy from fuel combustion provided for steaming (boiling) and drying the paddy. The heat energy has been supplied for drying the products in these mills by means of blowers. The average electrical energy consumption for drying and milling the paddy is about $100 \mathrm{kWh} /$ tonne to 250 $\mathrm{kWh} /$ tonne. The average heat energy supplied for boiling and drying the paddy had been found to be in the range of $1100 \mathrm{kWh} /$ tonne to $1360 \mathrm{kWh} /$ tonne. 


\section{Conclusions and Future Works}

The efficient energy utilization in the rice mills is a great challenging task to the researchers. The modern rice industries consume a large amount of energy in comparison with the traditional rice mills. This is evident in the chart shown in Figure 4.

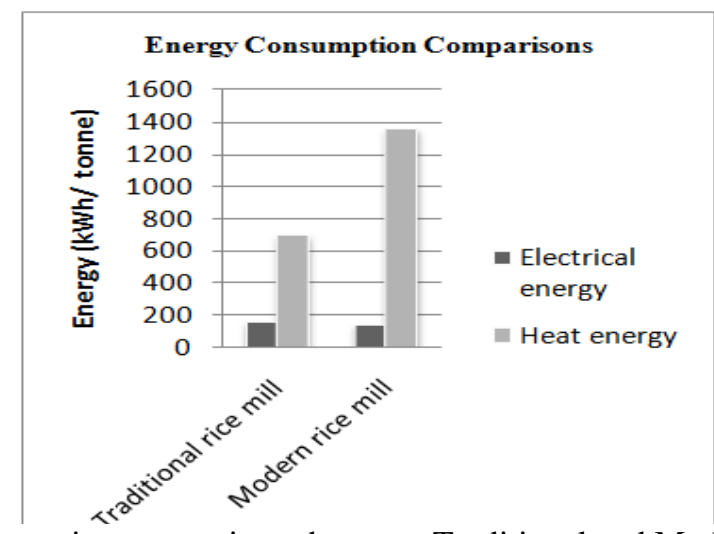

Figure 4: Energy consumption comparisons between Traditional and Modern Rice Mills

The chart in Figure 4 explains that the amount of heat energy required in Traditional mills is almost half of the energy required in the case of modern mills. Thus, by means of energy conservation in the rice industry, the consumption of fuels and electricity could be reduced. This survey will help in proposing the alternate energy source (Solar energy) for requirement of heat energy which is to assist in boiling and drying.

The following conclusions could be arrived with this survey.

- It is observed that a temperature rise of about 60 to $70^{\circ} \mathrm{C}$ could be achieved by Solar dryers.

- Additional thermal energy required for processing could be achieved by Fuel combustion process.

- The Solar and Fuel combustion system could be used as a Hybrid energy system.

- Almost 40 to $45 \%$ energy consumptions in the modern rice mills could be compensated by this system.

Thus, by the applications of Energy substitute technologies and better planning, the industrial energy crisis could be easily solved. The modern rice mills, which consume more thermal energy, could not be compared with the traditional rice mills in terms of their capacity. Furthermore, in the study area, the modern rice mills are found to be dominating among other types of mills. Since a major share of paddy had been found to be processed by modern rice mills, there is a lot of scope in the implementation of the Hybrid Solar Energy systems in these rice mills.

The following works could be considered in addition to the current work in the future.

- The feasibility of implementing the Solar dryer systems in other drying processes like coconut drying, turmeric curing fields could be surveyed.

- The research work to bring about the Solar water heater into operations in the Rice mills could be considered.

- The experimental analysis has to be carried out to understand the efficiency and performance of the systems.

- The Phase change materials could be considered in the system to bring about the Uniformity of the temperature in the Solar dryer system.

\section{Acknowledgements}

Author is heartily thankful to Dr. M. Easwaramoorthi, Dean and Professor, Department of Mechanical Engineering, Nandha Engineering College (Autonomous), Erode District, Tamil Nadu for his continuous advice, guidance and encouragement for preparing this manuscript.

\section{References}

[1] M. K. Shweta, S. B. Mahajanashetti and N. M. Kerur. 2011. "Economics of paddy processing: a comparative analysis of conventional and modern rice mills." Karnataka Journal of Agricultural Science 24(3): 331-335. http://web.inflibnet.ac.in/ojs/index.php/KJAS/article/download/730/677.

[2] S. K. Goyal, S. V. Jogdand and A. K. Agrawal. 2014. "Energy use pattern in rice milling industries - a critical appraisal." Journal of Food Science and Technology51 (11): 2907 - 2916. doi:10.1007/s13197-012-0747-3.

[3] www.woodenergy.ie

[4] http://www.worldenergy.org/publications/survey_of_energy_resources_2007/625.asp

[5] http://www.knowledgebank.irri.org/rkb/index.php/rice-milling/commercial-rice-milling-systems/husking 
Appendix - 1:

Table 1: Details collected in industrial survey (Traditional mills):

\begin{tabular}{|c|c|c|c|c|c|c|}
\hline \multirow[t]{2}{*}{ Company Name } & \multirow{2}{*}{ 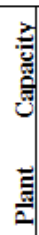 } & \multirow{2}{*}{ 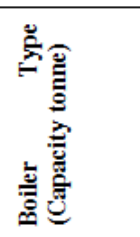 } & \multirow{2}{*}{ 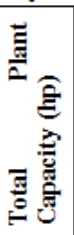 } & \multicolumn{2}{|c|}{$\begin{array}{l}\text { Electricity } \\
\text { Usage }\end{array}$} & \multirow{2}{*}{ 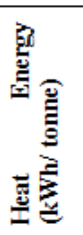 } \\
\hline & & & & 主 & 竒 & \\
\hline Palaniandavar Rice Mill, Nasiyanur & 4 & Steam $(1.0)$ & 80 & 2150 & 67.18 & 750.00 \\
\hline P.S.R Rice Mill, Chengapalli & 4 & Steam $(1.0)$ & 20 & 4000 & 125.00 & 687.50 \\
\hline P.R.P Modern Rice Mill, Chengapalli & 3 & Steam $(1.0)$ & 20 & 3500 & 145.83 & 625.00 \\
\hline Kittusamy Rice Mill, Chengapalli & 3 & Steam $(1.0)$ & 30 & 5000 & 208.50 & 833.30 \\
\hline Lakshmi Rice Mill, Vellode & 3 & Steam $(1.5)$ & 50 & 5500 & 225.00 & 583.30 \\
\hline
\end{tabular}

Appendix - 2:

Table 2: Details collected in industrial survey (Modern Rice mills):

\begin{tabular}{|c|c|c|c|c|c|c|c|c|}
\hline \multirow[t]{2}{*}{ S.No } & \multirow[t]{2}{*}{ Company Name } & \multirow{2}{*}{$\begin{array}{l}\text { Plant } \\
\text { Capacity } \\
\text { (tonne) }\end{array}$} & \multirow{2}{*}{$\begin{array}{l}\text { Boiler Type } \\
\text { (Capacity } \\
\text { tonne) }\end{array}$} & \multirow{2}{*}{$\begin{array}{l}\text { Total } \\
\text { Plant } \\
\text { (hp) }\end{array}$} & \multirow{2}{*}{$\begin{array}{l}\text { Dryer } \\
\text { (hp) }\end{array}$} & \multicolumn{2}{|c|}{ Electricity Usage } & \multirow{2}{*}{$\begin{array}{l}\text { Heat } \\
\text { Energy } \\
\text { (kWh/ } \\
\text { tonne) }\end{array}$} \\
\hline & & & & & & $\begin{array}{l}\text { kWh/ } \\
\text { month }\end{array}$ & $\begin{array}{l}\mathrm{kWh} / \\
\text { tonne }\end{array}$ & \\
\hline 1 & $\begin{array}{l}\text { K.S.V Modern Rice } \\
\text { Mill, Perundurai }\end{array}$ & 12 & Steam(2.0) & 125 & 16 & 14000 & 145.83 & 1250.00 \\
\hline 2 & $\begin{array}{lr}\text { Thirupathi } & \text { Modern } \\
\text { Rice } & \text { Mill, } \\
\text { Seenapuram. } & \\
\end{array}$ & 40 & Steam(3.5) & 300 & 30 & 30000 & 93.75 & 1340.00 \\
\hline 3 & $\begin{array}{l}\text { Saraswathi Rice Mill, } \\
\text { Perundurai }\end{array}$ & 13 & Steam(2.0) & 120 & 17 & 14500 & 139.37 & 1346.10 \\
\hline 4 & $\begin{array}{l}\text { Palaniyammal } \\
\text { Mill, Gobi }\end{array}$ & 16.5 & Steam(3.0) & 200 & 40 & 21500 & 162.87 & 1287.80 \\
\hline 5 & $\begin{array}{l}\text { S.S.M Modern Rice } \\
\text { Mill, Kanchikovil }\end{array}$ & 16 & Steam(2.5) & 150 & 18 & 7150 & 55.87 & 1171.80 \\
\hline 6 & $\begin{array}{l}\text { S.V.S Modern Rice } \\
\text { Mill, Kanchikovil }\end{array}$ & 40 & Steam(4.0) & 149 & 24 & 23000 & 71.87 & 1218.70 \\
\hline 7 & $\begin{array}{l}\text { Palanimurugan Rice } \\
\text { Mill, Gobi }\end{array}$ & 12 & Steam(2.0) & 100 & 20 & 11500 & 119.78 & 1250.00 \\
\hline 8 & $\begin{array}{l}\text { Arun Karthick Hi- } \\
\text { Tech Modern Rice } \\
\text { Mill, Thingalur }\end{array}$ & 18 & Steam $(3.0)$ & 150 & 15 & 17150 & 119.09 & 1388.8 \\
\hline 9 & $\begin{array}{l}\text { Sri Arumugam Rice } \\
\text { Mill, Modachur }\end{array}$ & 12 & Steam(1.5) & 120 & 20 & 13570 & 141.35 & 1458.3 \\
\hline 10 & $\begin{array}{l}\text { Sengodappan Rice } \\
\text { Mill, Modachur }\end{array}$ & 16.5 & Steam(1.5) & 145 & 15 & 12000 & 90.90 & 1212.1 \\
\hline 11 & $\begin{array}{l}\text { Kanthapa Modern } \\
\text { Rice Mill, Thingalur }\end{array}$ & 15 & Steam(3.0) & 165 & 15 & 21400 & 178.47 & 1333.30 \\
\hline 12 & $\begin{array}{l}\text { Sri Murugan Rice } \\
\text { Mill, Kanchikovil }\end{array}$ & 24 & Steam(2.5) & 147 & 23 & 28570 & 148.80 & 1416.60 \\
\hline 13 & $\begin{array}{l}\text { Brinthavan Modern } \\
\text { Rice Mill, Gobi }\end{array}$ & 14 & Steam(4.0) & 140 & 17 & 17000 & 151.78 & 1339.20 \\
\hline 14 & $\begin{array}{l}\text { Periyasamy } \\
\text { Mill, Gobi }\end{array}$ & 14 & Steam(2.0) & 135 & 20 & 12850 & 114.73 & 1517.80 \\
\hline \multirow[t]{2}{*}{ S.No } & \multirow[t]{2}{*}{ Company Name } & \multirow{2}{*}{$\begin{array}{l}\text { Plant } \\
\text { Capacity } \\
\text { (tonne) }\end{array}$} & \multirow{2}{*}{$\begin{array}{l}\text { Boiler Type } \\
\text { (Capacity } \\
\text { tonne) }\end{array}$} & \multirow{2}{*}{$\begin{array}{l}\text { Total } \\
\text { Plant } \\
\text { (hp) }\end{array}$} & \multirow{2}{*}{$\begin{array}{l}\text { Dryer } \\
\text { (hp) }\end{array}$} & \multicolumn{2}{|c|}{ Electricity Usage } & \multirow{2}{*}{$\begin{array}{l}\text { Heat } \\
\text { Energy } \\
\text { (kWh/ } \\
\text { tonne) }\end{array}$} \\
\hline & & & & & & $\begin{array}{l}\text { kWh/ } \\
\text { month }\end{array}$ & $\begin{array}{l}\mathrm{kWh} / \\
\text { tonne }\end{array}$ & \\
\hline 15 & $\begin{array}{l}\text { Kathiravan Rice Mill, } \\
\text { Modachur }\end{array}$ & 13 & Steam $(2.0)$ & 150 & 15 & 21400 & 205.70 & 1538.40 \\
\hline 16 & $\begin{array}{l}\text { Dhanalakshmi Rice } \\
\text { Mill, Gobi }\end{array}$ & 13.5 & Steam(1.5) & 112 & 14 & 10500 & 97.21 & 1296.20 \\
\hline 17 & $\begin{array}{l}\text { Vigneshwara } \\
\text { Mill, } \\
\text { Chengapalli }\end{array}$ & 2.2 & Steam(1.0) & 60 & 10 & 4285 & 243.60 & 1704.50 \\
\hline 18 & $\begin{array}{lr}\text { Sri Shiva } & \text { Shakthi } \\
\text { Rice } & \text { Mill, } \\
\text { Chengapalli } & \end{array}$ & 4.8 & Steam(1.5) & 60 & 12 & 8200 & 213.54 & 1302.00 \\
\hline 19 & $\begin{array}{l}\text { M.M.K Modern Rice } \\
\text { Mill, Nasiyanur }\end{array}$ & 13 & Steam(2.0) & 125 & 17 & 15700 & 150.95 & 1250.00 \\
\hline 20 & $\begin{array}{l}\text { Govithammal } \\
\text { Mill, Gobi }\end{array}$ & 15 & Steam(2.0) & 120 & 16 & 13500 & 112.50 & 1333.30 \\
\hline 21 & $\begin{array}{l}\text { Sri Shakthi Rice Mill, } \\
\text { Karukampalli }\end{array}$ & 21 & Steam $(2.5)$ & 135 & 20 & 18750 & 111.62 & 1428.50 \\
\hline 22 & $\begin{array}{lr}\text { Sri } & \text { Vengadeswara } \\
\text { Rice } & \text { Mill, } \\
\text { Kavinthapadi } & \end{array}$ & 38 & Steam(3.5) & 280 & 35 & 28000 & 125.00 & 1513.10 \\
\hline
\end{tabular}

